\title{
\$ Five Scholarly Open Access Publishers
}

doi:10.5260/chara.13.4.5

Date of Review: February 15, 2012

Academy Publish Composite:

AOSIS Open Journals Composite:

BioInfo Composite:

ScienceDomain International Composite:

Scientific Research Publishing Composite:

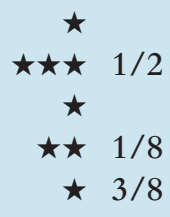

Reviewed by: Jeffrey Beall

Auraria Library

University of Colorado Denver

1100 Lawrence St., Rm. 118-B

Denver, CO 80204

<jeffrey.beall@ucdenver.edu>

\begin{abstract}
This review critically examines five international scholarly publishers that publish academic journals using the gold (author pays) Open Access model. The author-pays model is changing scholarly publishing because authors, rather than libraries or other subscribers, become the publishers' customers, an arrangement that creates a built in conflict of interest. The more articles a publisher accepts, the more revenue it earns. New gold Open Access publishers are appearing almost weekly, and many are engaged in unethical practices. The review covers four predatory publishers, Academy Publish, BioInfo, ScienceDomain International, and Scientific Research Publishing, and one legitimate publisher, AOSIS Open Journals.
\end{abstract}

\section{Pricing Options}

Each of these publishers is Open Access and each uses the "author pays" (gold Open Access) model to support the publication of the journals. The description and analysis below cover the charges an author pays upon publication of a manuscript. A couple of the publishers (e.g. Scientific Research Publishing) also sell print subscriptions to their online, Open Access journals.

\section{ACADEMY PUBLISH}

This publisher states that it charges $\$ 1,000$ for journal articles and $\$ 800$ for chapters in edited books. However, it also states that it currently offers a $65 \%$ discount.

\section{AOSIS OPEN JOURNALS}

According to this publisher's manager, "The publication fee of our Open Access journals range from ZAR0.00 - ZAR715.00 per A4 output page in PDF format for an accepted manuscript. This fee includes the publication of all articles in four formats PDF, HTML, XML, and EPUB." The currency is the South African Rand (ZAR), and there are currently about eight ZAR to the U.S. dollar.

\section{BIOINFO}

This publisher has different fees for each of its many journals. One example is the journal entitled BIOINFO Library and Information Science. For this title, the fee is either $\$ 325$, which includes a single offprint for the corresponding author, or $\$ 275$ without the offprint. These charges are exclusive of any bank charges. Most of the author fees for the publisher's other journals are close to these amounts. The publisher also sells hard copies of its Open Access journals for $\$ 100$ per issue.

\section{SCIENCEDOMAIN INTERNATIONAL}

This publisher states, "Authors have to pay 500 US Dollar / 320 GBP* / 370 Euro, as Publication Charge (PC), for publication of each manuscript in any SDI journal." The publisher offers discounts ranging from $10 \%-50 \%$ for authors from lower-income countries or for authors with institutional membership, the cost of which ranges from $\$ 1,000$ to $\$ 4,000$, depending on the institution's size. Also offered is a special membership with discounted prices based on the number of accepted articles per year.

\section{"At a Glance" Comparative Review Scores}

The maximum number of stars in each category is 5 .

\begin{tabular}{|c|c|c|c|c|c|}
\hline & $\begin{array}{l}\text { Academy } \\
\text { Publish }\end{array}$ & $\begin{array}{l}\text { AOSIS Open } \\
\text { Journals }\end{array}$ & BioInfo & $\begin{array}{l}\text { ScienceDomain } \\
\text { International }\end{array}$ & $\begin{array}{c}\text { Scientific Research } \\
\text { Publishing }\end{array}$ \\
\hline Composite & $\star$ & $\star \star \star \quad 1 / 2$ & $\star$ & $\star \star 1 / 8$ & $\star 3 / 8$ \\
\hline Content & $\star$ & $\star \star \star 1 / 2$ & $\star$ & $\star 1 / 2$ & $\star 1 / 2$ \\
\hline $\begin{array}{l}\text { User Interface/ } \\
\text { Searchability }\end{array}$ & $\star$ & $\star \star$ & $\star$ & $\star$ & $\star$ \\
\hline Author Fee Pricing & $\star$ & $\star \star \star \star$ & $\star$ & $\star \star$ & $\star \star$ \\
\hline Licensing & $\star$ & $\star \star \star \star \star 1 / 2$ & $\star$ & 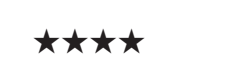 & $\star$ \\
\hline
\end{tabular}




\section{SCIENTIFIC RESEARCH PUBLISHING}

The author fees vary by title. Generally, the publisher charges $\$ 300$ $\$ 500$ for the first ten pages of each manuscript, plus $\$ 50$ for each additional page.

\section{Product Description \\ ACADEMY PUBLISH (<http://www.academypublish.org/>)}

Based in Cheyenne, Wyoming, Academy Publish is a relatively new entrant into the scholarly Open Access publishing industry. Its Web site appeared in May, 2011. Currently publishing four journal titles, Academy Publish also has plans for several Open Access, online monographs to be published in 2012. Both the journals and the monographs have a broad coverage, a strategy that increases the number of submissions that can be accepted. For example, one of its journal titles is the Journal of Medical Research and Science, and one of its monograph titles is Nanotechnology.

Academy Publish's Web site is well-designed and easy to navigate. Throughout the site, the publisher sings the praises of Open Access, letting potential authors know that if they submit to Academy Publish, they are helping promote a worthy movement. The journals all publish quarterly, and each has had two issues published so far, but the issues are not dated, and the content is minimal. The journals have ISSNs, but the articles lack DOIs. The site offers no search functionality other than clicking on links to the journals and books.

For each journal, there is a link to the editorial board. The Journal of Computer and Information Technology only lists two "editors" (as editorial board members are called on this site). The other journals list three, four, and two editorial board members. It's fair to say this publisher is having trouble attracting editorial board members and article submissions.

\section{AOSIS OPEN JOURNALS (<http://www.openjournals.net/>)}

Unlike the other four publishers covered in this review, AOSIS is a legitimate Open Access publisher. Based in South Africa, this publisher's portfolio includes 16 peer-reviewed journals. AOSIS (the name means African Online Scientific Information Systems) also claims to be a book publisher, but only a single book is listed on the site. The publisher is a member of the Open Access Scholarly Publishers Association and CrossRef. It operates almost like a cooperative, providing publishing services to learned societies in southern Africa. This arrangement creates an economy of scale and allows the organizations to contract out their journal publishing to AOSIS.

The journals are specialized and include Koedoe - African Protected Area Conservation and Science and the SA Journal of Human Resource Management. The journals are high quality and each has an editor and an established editorial board. Each journal has its own Web site; generally the journal's Web sites are part of the organizations' Web sites that they belong to.

The publisher also sells hard copies of each journal. From the main Web site it almost looks like that is the only way to access the journals - by buying a hardcopy. To access the Open Access articles, users have to go to each journal's Web site. The publication fees are clearly stated on each journal's page.

\section{BIOINFO (<http://www.bioinfo.in/index.php>)}

The most striking thing about this publisher is the large number of journal titles it publishes - over 300 at last count. However, looking closer at the individual journals, one observes that many are mere templates, devoid of content. For example, the journal BIOINFO Animal Husbandry lists a single editorial board member and lacks any articles. Another example is the International Journal of Computer Graphics and Visualization, which has a single issue published (vol. 1 , no. 1, 2011), which contains a mere two articles. Browsing through the titles, it's hard to find one with any article content. Some of the journals have ISSNs, but on most the placeholder for the ISSN in the template is left blank.

Despite the publisher's name, some of its journals cover non-scientific topics. One example is the International Journal of Literature and Language, which doesn't have any articles yet. BioInfo states that all of its journals are peer-reviewed and Open Access, yet boasts "Unmatched efficiency, with an average of 1 months [sic] from submission to publication." BioInfo claims also to have business relationships with EBSCO, Wolters Kluwer, and ProQuest, and other established publishers. The Web site is slow, hard to navigate, and lacks any search functionality. Some pages have printing disabled, and many pages use an annoying bright pink font. The News link at the top of the home page leads to a page with job openings at BioInfo. The first is "Trainee Website Designer," and there are four openings.

There are several Open Access publishers that are basically oneman operations, and BioInfo is one of them. In this case the man is Virendra Gomase, whose title is President and Editor in Chief, Bioinfo Publications. His LinkedIn page says, "Bioinfo Publications is a rapidly growing academic publisher with more than 318 Open Access PEER-REVIEWED journals covering a wide range of academic disciplines."

\section{SCIENCEDOMAIN INTERNATIONAL (<http://www.sciencedomain.org/>)}

This publisher publishes 19 peer-reviewed, Open Access journals. The journals cover biological, medical, physical, and social sciences. Three journals lack any content, the other 16 began publication in 2011, and most publish quarterly (including the Annual Review \& Research in Biology). The journal titles are notable for gratuitously using geographic terms in their titles, e.g., American Journal of Tropical Medicine and Public Health, British Journal of Pharmaceutical Research. The word "International" appears in three other titles. The publisher lists offices in the U.K, the U.S., and India but is really an Indian company that operates out of India. Thus the geographical terms in the titles are an attempt to deceive potential authors.

ScienceDomain makes a big deal about promoting Open Access. On the top of its home page there is a link that says "Nobel Laureats [sic] $\&$ Luminaries" that leads to a page with quotes from Nobel Prize winners supporting Open Access. It's a clear attempt to link the winners with the publisher, even though none has any connection with it.

There is no search functionality on the site, though the publisher purports to be indexed by almost every abstracting and indexing service imaginable, including ProQuest and EBSCO. The journals carry ISSNs but no other standard numbers.

Regarding the journals' editorial boards, there appear to be some unprofessional practices. For example, the American Chemical Science Journal doesn't list any editor or editorial board member, despite having published three issues already. Some journals do not list a chief editor but list only "associate editors."

Two of the titles on the list are actually title changes. That is, the journal is listed twice, once for the old name and once for the new, but this fact is not clearly indicated on the journals list. 


\section{SCIENTIFIC RESEARCH PUBLISHING (<http://www.scirp.org/>)}

Scientific Research Publishing (SCIRP) currently publishes 159 Open Access, peer-reviewed journals. Most of the titles began publishing in 2010 and 2011. The publisher also organizes conferences and then publishes the proceedings, and it also publishes edited monographic anthologies. The print volumes of the conference proceedings are not Open Access and are sold in print only. In terms of coverage, the journals cover physical and health sciences, computer science, engineering, social sciences, humanities, and mathematics.

The publisher purports to operate out of Irvine, California, and it may have an office there, but it is really a Chinese operation. The journals have ISSNs for both their print and online versions, and the articles have DOIs, as the publisher is a CrossRef member.

Little information about this publisher is available; they are secretive. The About Us page is brief and only provides a vague, short description of the publisher. A 2010 article in Nature (Sanderson, 2010) details unethical practices that SCIRP allegedly committed. The article says that the publisher copied articles from other publishers and included them as articles in several of their journals. Additionally, it details how the publisher listed some people as members of its editorial boards without their knowledge or permission.

Scientific Research Publishing is widely known for its use of spam e-mails to solicit article submissions and editorial board service. The site is popular with Chinese authors, many of whom get a monetary incentive (Shao, 2011) for publishing abroad. Also, its author fees are on the low side, a strategy that increases article submissions, especially from lower-income countries.

\section{Critical Evaluation}

\section{ACADEMY PUBLISH}

This brand-new operation hopes to capitalize on the Open Access movement by accepting as many articles as possible and enjoying the author fees they generate. While the site itself is attractive, it still could easily have been designed and set up in a week's time, and it contains very little scholarly content. Still unclear is why such an operation would sprout up in Cheyenne, Wyoming. It seems to operate like an old mining claim, only it is staking out scholarly article titles rather than a vein of ore, and hoping for riches.

The publisher is not transparent, making it hard to understand its motives and backers. The Contact Us page is a Web form. It does list a street address, and a look at Google maps reveals a four-story office building on a lonely Cheyenne street a few blocks from the Wyoming state capitol. Most of the building's occupants are law firms.

The name "Academy Publish" is awkward. Perhaps it sounds more professional in another language. We don't know who is behind this operation. It has Twitter and Facebook accounts, but they reveal little. The lack of scholarly content indicates that researchers are mostly rejecting this so-called publisher, and I recommend that everyone do the same.

\section{AOSIS OPEN JOURNALS}

This publisher creates an economy of scale by providing quality publishing services for several South African learned societies. This publisher is transparent, clearly listing all contact information, author fee prices, and other important content. The journals vary greatly in coverage and include both health science and theology journals, among others. The journals have respected editors and authentic editorial boards.

Some of the journals formerly published in print only. They have changed their publishing model and now use AOSIS to publish their content using the Open Access model. One example is the journal Koedoe: African Protected Area Conservation and Science. The current issue is volume 54 (2012). The site contains all volumes available as Open Access PDF back to volume 1 (1958). This retrospective scanning and republishing represents an amazing achievement in Open Access publishing.

AOSIS is a member of the OASPA and strives to maintain open and ethical practices that relate to Open Access publishing. It is a model for other prospective and existing Open Access publishers. One area where it has a great potential for growth is Open Access monographs. It has only one so far, and a successful publisher like this one should direct efforts at expanding in areas such as this one.

\section{BIOINFO}

This publisher is another greedy startup in the field of Open Access publishing. It follows the now well-established recipe for setting up shop as a scholarly Open Access publisher. BioInfo has scores of ostentatious journal titles, a Web site that declares partnerships with the best indexers, and branch offices around the world, at least according to the publisher. The only thing it's missing is scholarly content. It's obvious that when a brand-new publisher simultaneously launches over three hundred journals that its true mission is not to advance scholarly communication but to exploit the Open Access model for a quick and easy profit.

This Web site's particular mission is to generate revenue for its owner, Virendra Gomase. Writers on Open Access have described the problem of low startup barriers for scholarly publishing operations, especially in comparison to the traditional print model which required lots of capital and human resources to get going. BioInfo is the poster child of easy access to the scholarly publishing industry. All it needed was a Web site and the creativity to come up with journals names that weren't already taken, at most a week's work

BioInfo is already showing signs of failure. It has attracted few article submissions, and it's as if the owner has already lost interest in pursuing the business any further. Researchers are slowly catching on to abusive operations such as this one and avoiding them.

\section{SCIENCEDOMAIN INTERNATIONAL}

This publisher is a good example of a startup that tries to promote itself by closely attaching its mission and values to those of the Open Access movement itself. The message is that if you publisher with them, you are a noble and benevolent researcher, making you work available to all, especially those from developing countries.

But almost everything about ScienceDomain International (SDI) is fraudulent. Its main page claims it is "a leading Open Access publisher, publishes high-quality, peer reviewed, international journals in various sectors of science, technology and medicine." In fact, it is new and is among the lowest tier of scholarly publishers. Many startups initially offer discounts to attract submissions. This one listed a $60 \%$ discount off author fees until March 31, 2012, reducing the normal $\$ 500$ fee down to $\$ 200$.

To look scientific, the site's main page has an image of a double helix and a picture of a human head that looks like an MRI image. SDI falsely boasts that its scarce content is indexed in more than 21 index- 


\section{Academy Publish Review Scores Composite: $\star$}

The maximum number of stars in each category is 5.

\section{Content:}

Less than a year old, this publisher has very little content.

\section{User Interface/Searchability:}

No effort is given to provide any search functionality other than A-Z lists of its journals and books.

\section{Author Fee Pricing:}

Given that this site will be scorned by serious scholars, no author fee is too low.

\section{Licensing:}

This publisher doesn't mention Creative Commons and doesn't seem to understand licensing.

\section{AOSIS Open Journals Review Scores Composite: $\star \star \star \star 1 / 2$}

The maximum number of stars in each category is 5.

Content:

$1 / 2$

Many of its 15 respected journals are continuations of former print journals, and at least one includes full back files, all Open Access.

\section{User Interface/Searchability:}

The Web site is crowded, and searching includes simple and advanced searching yet is clunky.

\section{Author Fee Pricing:}

Licensing:

Clearly stated, and the site gives good explanations of the Open Access model.

\section{BioInfo Review Scores Composite: $\star$}

\footnotetext{
The maximum number of stars in each category is 5 .
}

\section{Content:}

This site is a scholarly wasteland.

\section{User Interface/Searchability:}

The only search functionality is the A-Z list of journals and the list of journals by subject.

\section{Author Fee Pricing:}

This outfit should pay for articles rather than the other way around.

\section{Licensing:}

Deceptive. The publisher requires authors to sign over copyright but claims the articles are available under a CC attribution license. 


\section{ScienceDomain International Review Scores Composite: $\star \star 1 / 8$}

The maximum number of stars in each category is 5 .

\section{Content:}

$1 / 2$

Because this publisher has successfully fooled some people, it contains both poor and good articles.

\section{User Interface/Searchability:}

An A-Z list of journals is available, as is a Google Custom Search box.

\section{Author Fee Pricing:}

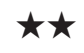

With the discount, the price is on the low side among bottom-tier publishers.

\section{Licensing:}

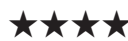

Uses the $\mathrm{CC}$ attribution license and it is stated on the articles.

\section{Scientific Research Publishing Review Scores Composite: $\star 3 / 8$}

The maximum number of stars in each category is 5 .

\section{Content:}

\section{$1 / 2$}

One of the biggest OA publishers, yet the content is only average because many authors of high quality publishers would never publish here.

\section{User Interface/Searchability:}

It has a simple search box (but the response is slow) plus an A-Z list of journals.

\section{Author Fee Pricing:}

On the low side, a strategy that increases article submissions from authors without grants.

\section{Licensing:}

Its articles carry a copyright statement.

ing services, but some it lists, such as Google Scholar, are comprehensive and do not screen for quality.

I expect this publisher to increase the number of journal titles it publishes over the next year. Otherwise, given its current, relatively small portfolio of 19 titles, it probably won't survive the highly competitive business of gold Open Access scholarly publishing.

\section{SCIENTIFIC RESEARCH PUBLISHING}

This publisher exists for two reasons. First, it exists to exploit the author-pays Open Access model to generate revenue, and second, it serves as an easy place for foreign (chiefly Chinese) authors to publish overseas and increase their academic status.

Scientific Research Publishing (SCIRP) has cleverly succeeded in generating lots of article submissions. Though it is really a Chinese operation, it operates out of Southern California. Its author fees are relatively low, a strategy that successfully attracts a large number of submissions.

The publisher is a member of Cross-Ref and correctly assigns and uses DOI numbers. Its journals also have ISSNs. Not all of the articles published on this site are of low quality. Because the publisher is so successful at making its Web presence seem legitimate, it has attracted some quality article submissions. Nevertheless, it is really little more than a vanity press.

This publisher reveals little about itself; it is not transparent. The Contact Us page is a bare Web form, and it lists no telephone contact. SCIRP has something to hide, and researching this publisher is difficult because it reveals so little about itself, its peer-review process, and its operations. 


\section{Contact Information \\ Academy Publish \\ Publishing Services LLC \\ 2120 Carey Avenue \\ Cheyenne, WY 82001 \\ Fax: (888) 467-5318 \\ URL: <http://www.academypublish.org/>}

AOSIS Open Journals
Postnet Suite \#55
Private Bag X22
Tygervalley, Bellville 7536
South Africa
Phone: $\quad \begin{aligned} & \text { 0861000381 (within South Africa) } \\ & \text { +27219752602 (International) }\end{aligned}$
$\begin{array}{ll}\text { Fax: } \quad \text { 0866741909 (within South Africa) } \\ \text { +27219754635 (International) }\end{array}$
URL: $\quad$ <http://www.openjournals.net/>

\section{BioInfo}

Bioinfo Publications

49, Vighnahar Shopping Complex

Front of Overseas Bank, Sector-12

Kharghar, Navi Mumbai-410210

India

Fax: $\quad+91-22-27743967$

E-mail: <editor@bioinfo.in>

URL: <http://www.bioinfo.in/index.php>

\section{ScienceDomain International}

Address: U GF, DLF City Phase-III

Gurgaon, 122001

Delhi NCR

India

Note: A UK and a USA address are also provided.

Fax: $\quad$ +91 11-66173993 (India office)

E-mail: <contact@sciencedomain.org>

URL: <http://www.sciencedomain.org/>

\section{Scientific Research Publishing \\ P.O. Box 54821 \\ Irvine CA 92619-4821 \\ E-mail: <service@scirp.org> \\ URL: <http://www.scirp.org/>}

The site has the standard Facebook, LinkedIn, and Twitter icons, but clicking on them doesn't lead you to the publisher's page on each service. Instead, it leads you to your account and generates a blurb promoting the publisher that it wants you to post. Scientific Research Publishing is among the sneakiest and most clever predatory Open Access publishers I have seen.

\section{Licensing}

This section describes the licenses under which the publishers release their scholarly content. Most all of the content is Open Access, so no end-user contracts are applicable. In gold Open Access publishing, the authors, not the journal consumers, are the publishers' customers. This is a major change from the traditional model in which publishers aimed to please libraries and others consumers of their content.

\section{ACADEMY PUBLISH}

This site doesn't use a standard license. Instead, it simply states that its content is Open Access and that "authors retain ownership of the copyright for their articles." However, on the terms and conditions page, the publisher states, "Unless otherwise stated, the materials available at Academy Publish Web site are the property of the Publishing Services LLC and are protected under U.S. and international copyright laws and conventions." It appears that this publisher understands little about Open Access licensing practices and used contradictory boilerplate content on its Web site.

\section{AOSIS OPEN JOURNALS}

The publisher states, "In the AOSIS OpenJournals portfolio, all scholarly journals are published under the Creative Commons Attribution 3.0 Unported License."

\section{BIOINFO}

The publisher states, "Bioinfo Publications Open Access articles distributed [sic] under the terms of the Creative Commons Attribution License ...”

\section{SCIENCEDOMAIN INTERNATIONAL}

For each journal, the publisher states, "The copyrights of all papers published in this journal are retained by the respective authors as per the 'Creative Commons Attribution License' ..."

\section{SCIENTIFIC RESEARCH PUBLISHING}

This publisher adds its own copyright statement to each article (e.g., Copyright (C) 2011 SciRes) yet simultaneously declares the articles it publishes are Open Access. It places some limits on authors' reuse of their own submissions. Other than the copyright statement, the publisher makes no mention of any standard license.

\section{Authentication}

Users need no authentication to access these publishers' content. Except for some conference proceedings that Scientific Research Publishing publishes only in print, all content is made available freely over the Internet.

\section{Author's References}

Sanderson, Katharine. "Two new journals copy the old." Nature 463 (14 January 2010): 148.

Shao, Jufang, and Huiyun Shen. "The outflow of academic papers from China: Why is it happening and can it be stemmed?" Learned Publishing 24 (2011): 95-97.

\section{About the Author}

Jeffrey Beall is Metadata Librarian at Auraria Library, University of Colorado Denver. He earned his MSLS degree from the University of North Carolina at Chapel Hill. He also holds an MA degree in English from Oklahoma State University. He has worked as an academic librarian for 21 years. His research and articles have been published in numerous journals including American Libraries, College \& Research Libraries, and Cataloging \& Classification Quarterly.

For more information on questionable Open Access publishers, please see Jeffrey's blog, Scholarly Open Access, at <http://scholarlyoa.com/>. 